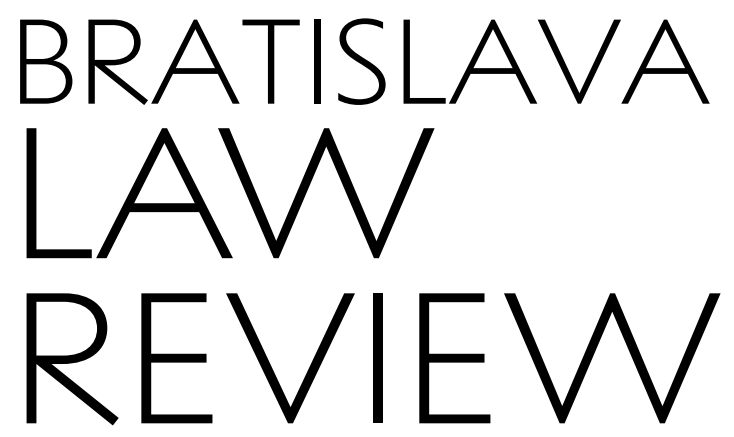

PUBLISHED BY

THE FACULTY OF LAW, COMENIUS UNIVERSITY IN BRATISLAVA

ISSN (print): $2585-7088$

ISSN (electronic): 2644-6359

\title{
LOYALTY IN CIVIL-LAW RELATIONSHIPS AS FOUND IN THE POLISH LAW / Ewa Lewandowska
}

Ewa Lewandowska, PhD.

University of Warmia and Mazury

in Olsztyn, Faculty of Law and

Administration, Department of Civil

Law and International Private Law;

Warszawska 98

10-702 Olsztyn; Poland:

e.lewandowska@uwm.edu.pl.

ORCID: 0000-0001-8369-6290
Submitted: 12 March 2020

Accepted: 10 May 2020

Published: 31 August 2020

\begin{abstract}
This paper discusses manifestations of loyalty as found in selected civil-law regulations, as well as the possible consequences of disloyalty, either during negotiations or for the duration of the obligation relationship, and as exemplified by Actio pauliana. Furthermore, it explores situations where 'contractual' loyalty stands in conflict with behaviour loyal towards other participants in the economy. It has been established that the categories of norms wherein broadly understood loyalty plays a special role are a part of the civil-law principles. It has been demonstrated that due to the unique nature of each situation, the introduction of the duty of loyalty as a general directive would be undesirable.
\end{abstract}

Key words: loyalty, culpa in contrahendo, obligation, form of juridical acts, Actio pauliana, simulation, simulated authorship, civil law principles, Polish law, civil law

\section{Suggested citation:}

Lewandowska, E. (2020). Loyality in Civil-Law Relationships as Found in The Polish Law. Bratislava Law Review, 4(1), 33-42. https://doi.org/10.46282/blr.2020.4.1.169

\section{INTRODUCTION}

The matter of loyalty in the law raises many interesting questions discussed even today in world literature (Luo \& Ye, 2019; Rauterberg \& Talley, 2017; Sørensen, 2010). The old Polish saying 'easier promised than done' still holds true (Świerczyńska, 2001, p. 172). ${ }^{1}$ Civil-law entities assume various obligations which they sometimes fail to perform properly or at all. Such failures have many reasons - starting from an honest mistake, through an unfortunate coincidence, ignorance, or impossibility to complete all formalities, and ending with a lack of need or even deliberate acts e.g. when a debtor operates from day one on the assumption that their creditor will not take legal action. Loyalty is a fuzzy term that nevertheless occupies a major position in ethics, philosophy, sociology, economy and the law. As such, it is subject to multiple interpretations.

Loyalty and consequences of the reverse are discussed in many civil-law regulations. Faithfulness is brought up explicitly in legislation on spousal relationships (Art. 23 of the Polish Family and Guardianship Code ${ }^{2}$ ) which intuitively construes the

\footnotetext{
${ }^{1}$ Incidentally - in copyright, a proverb included in publication title is regarded as a common good in the public domain (that can be used); such standpoint was adopted by the Supreme Court in the judgment of 4 March 2002, case reference No. V CKN 750/00 (lex database, No. 56851), (Grzybczyk, 2012, p. 161; Trzebiatowski, 2011); compare also: judgment of the Administrative Court in Warsaw from 23 December 2014, case reference No. I ACa 703/14 (lex database, np. 1768748).

${ }^{2}$ Act of 25 February 1964, Family and Guardianship Code, Dz.U. 2017, item 682, hereinafter: the FGC.
} 
notion as a commitment of the spouses to refrain from engaging in extramarital sexual activity. However, judicial practice suggests that it is not only adultery which may be regarded as unfaithfulness (cf. Winiarz, 2010, p. 291), which implies a broader understanding of marital faithfulness as a duty of mutual loyalty (cf. Witte, 2001). Aspects of loyalty may be found in several areas, i.a. in rulings based on general clauses such as social and economic purpose of rights, the principles of community coexistence (compare: Art. 5 of the Polish Civil Code, hereinafter referred to as the $\mathrm{CC}^{3}$ ) and good faith (compare: Art. 172 et seq. of the CC); (see also Wirtz, 2018). Loyalty may be interpreted in keeping with the principle of pacta sunt servanda or abstractly as loyal behaviour towards the other party, 'the contracting party' (Lekkas \& Tzanakopoulos, 2014). Disloyalty and a breach of contractual fairness are declared if the services rendered by both parties are of glaringly unequal value (compare: Art. 388 of the CC); (see Lewaszkiewicz-Petrykowska, 1973, p. 180 et seq.; Veljanovski, 2007, p. 151).

Loyalty appears to be a major theme in civil law, even though not referred to per se in any general provision of the law. This paper presents selected legal regulations that manifest the obligation to uphold loyalty. The main aim is to show that loyalty is understood in more than one sense depending on the relevant facts of the case and therefore requires no separate lex generalis.

\section{NEGOTIATION STYLE}

Polish legislation invokes loyalty as early as at the level of pre-contractual negotiations between parties. The legitimacy of pre-contractual liability relies on the fact that the legal relationship between the parties, based on the mutual duty of loyalty, is established at the moment of initiating the negotiations. Art. 72.2 of the CC sets forth that the party which commenced or conducted negotiations in violation of good practices, in particular with no intention of concluding the contract, shall be obliged to redress the damage that the other party suffered as a result of their reliance on the conclusion of the contract.

The Civil Code addresses one special case, i.e. the provision of information with the preservation of confidentiality. According to Art. $72^{1}$ of the CC, the duty of loyalty requires the receiving party to neither disclose said information, hand it over to other persons, nor use it for the party's own purposes unless the parties agreed otherwise.

In this case, legislation establishes the duty of loyalty in the form of a general clause of good practices, construed as a negotiation principle grounded in contractual fairness and customarily accepted ethical norms. A violation of good practices occurs i.e. when a party has no real intention of concluding the contract (and simply misleads the other party), breaks off negotiations at the last minute without reason, or conducts competitive negotiations (Czub, 2018, p. 685). Thus, legislation requires fair play even before a definitive, legally binding arrangement is created. Initiating and conducting negotiations in bad faith, i.e. knowing that an agreement will not be reached, constitutes a basis for seeking damages to the extent of the so-called negative contractual interest, i.e. a loss incurred by expecting the conclusion of the promised contract, under the concept of ex culpae in contrahendo (see also Colombo, 1993; Erp, 2004; Han, 2014; Köhler, 2004, p. 82).

\footnotetext{
${ }^{3}$ Act of 23 April 1964, Civil Code, Dz.U. 2018, item 1025, hereinafter: the CC.
} 


\section{OBLIGATION}

An obligation consists in that the creditor may demand performance from the debtor and the debtor shall render the performance (Art. 353 of the CC). In obligation law, loyalty is by design a vague term that burdens the debtor with an indefinite obligation (precisely defined in the context of particular situations that occur during obligation performance); (see Opalska, 2013, pp. 231-232; Pokrzywniak, 2003, p. 885). A loyal debtor performs their obligation according to its content and in a manner corresponding to its social and economic purpose and to the principles of community coexistence, and where there exist customs in that regard - also in a manner corresponding to these customs (Art. 354 of the CC). The consequences of non-performance or improper ${ }^{4}$ performance of the obligation may vary depending on the type of breach, its causes, and effects (see Veljanovski, 2007, p. 109 et seq.). Contractual liability is governed chiefly by the provisions of Art. 471-486 of the CC, but also by specific provisions of the norm outlined in Art. 487-497 of the CC, and by other statutory regulations applicable to the particular relationship of obligation (Zagrobelny, 2008, p. 844). ${ }^{5}$

In practice, it is common to apply Art. 471 of the CC which sets forth that a debtor who fails to keep their promise to the creditor (to perform or properly perform the obligation) is obliged to redress the damage arising from non-performance or improper performance of said obligation. ${ }^{6}$ The provision has a rather broad wording and allows to take into account the type of service when applied. Article 471 of the CC may give rise to liability for breaches of non-competition clauses that prevent a party from competing against the other, in an agreed time frame and scope, after their legal relationship has expired $^{7}$. In principle, the restraint of competition has a correlate in the payment of an adequate sum of money by the other party for the duration of the non-compete (though the pecuniary aspect is not materially important and may be excluded by the parties). Legislation neither defines non-competition nor provides examples thereof. Thus, it actually refers to loyal behaviour which may involve an abstention from competitive interests, competitive activity, or non-disclosure of particularly important information. Ideally, the parties should from time to time precisely stipulate the premises and the terms of non-competition.

The duty to uphold loyalty for the duration of the obligation is also exemplified by provisions on the impossibility of performance, i.e. Art. 387.2 and Art. 493 of the CC. The former sets forth that the party which, at the moment of the conclusion of the contract knows of the impossibility of the performance, should inform the other party thereof (put the other party right). This is precisely the behaviour expected of a loyal counterparty. Taking any other course of action obliges the party in question to redress the damage

\footnotetext{
${ }^{4}$ For instance, improper performance of an obligation may involve failure to meet a deadline, the manner of performance, or the quality of the service rendered.

${ }^{5}$ For more information on liability see e.g. works of Jugastru (2012) and Mangu (2015).

6 This regulation was invoked e.g. by the Supreme Court in the judgment of 7 July 2017. The Court ruled that a failure to perform obligations in a timely fashion constitutes non-performance, which gives rise to compensation liability for the loss incurred (Art. 471 of the CC), see: judgment of the Supreme Court of 7 July 2017, case reference No. V CSK 660/16 (lex database, No. 2350004); compare also: judgment of the Supreme Court of September 18, 2014, case reference No. V CSK 625/13 (lex database, No. 1515459), in which the Supreme Court declared that pursuant to Art. 471 of the CC, the renter's failure to return the object of rent in a timely fashion entitles the owner to claim damages for the gain he could have obtained, had the property been returned in time.

7 With reservation to regulations lex specialis, such as: Art. 7646 of the CC (activity of an agent), Art. 211 of 15 September 2000, Code of Commercial Companies, Dz.U. 2017, item 1577, Art. $101^{1}$ et seq. of the Act of 26 June 1974, Labor Code, Dz.U. 2018, item 917.
} 
which the other party incurred by having entered into the contract oblivious of the impossibility of the performance (initial impossibility). In turn, Art. 493 of the CC refers to the situation in which one of the parties causes or contributes to the impossibility of performance (is liable for the circumstances that have produced the impossibility) after the contract has effectively been concluded (subsequent impossibility). Such behaviour is an even more glaring case of disloyalty. The injured party may, according to their own choice, either demand the redress of the damage resulting from the non-performance of the obligation or repudiate the contract. In reciprocal contracts, in the event of partial impossibility to render performance by one of the parties, the other party may terminate the contract if partial performance would not have significance for it given the nature of the obligation or on account of the purpose of the contract intended by that party and known to the party, whose performance has become partially impossible.

\section{THE FORM OF JURIDICAL ACTS}

Art. $353^{1}$ of the CC stipulates that the main principle governing obligation law shall be the freedom of contract (libertas contrahendi), which emphasizes the competence of the parties to shape their reciprocal relations inter partes (see also Kaczorowska, 2011, p. 15). However, the principle has its limitations. For instance, the scope of competence varies depending on several factors, i.e. the characteristics of the entity ${ }^{8}$ and the type of civil-law relationship in question 9 . Additionally, the freedom of contract is limited by provisions requiring a specific form of juridical act (compare e.g.: Art. 158, 660, 720 of the CC). However, since the said regulations are exceptions, in all other situations the parties are free to conclude contracts in the form of their own choice, also in speech.

Oral contracts are commonly and effectively concluded in the course of normal daily-life activities. Without a doubt, they streamline civil-law procedures thanks to the absence of any formalities involved and their performance is usually instantaneous. However, should the performance be postponed, an oral contract entails a significant risk. In the event of a dispute, and particularly a non-performance of an obligation, oral form of the contract creates difficulties in proving the contents of the contract or even its conclusion. In principle, $^{10}$ the parties may produce evidence by calling witnesses, presenting documents which imply the conclusion of the relevant contract, etc. Problems start in the absence of said evidence. If one of the parties renounces the contract (behaves disloyally), the unofficial character of the contract may prove disadvantageous, not due to the lack of any specific regulation, but as a consequence of the choice made by the parties in selecting the form of the contract. Mutual trust in civil-law relationships, though impossible to fully eliminate, has its limits.

The form of juridical act is of material importance during the disposition of property in case of death (mortis causa). Contractual titles to inheritance are not honoured in Polish law. ${ }^{11}$ Legislation stipulates that disposition of the property in case of death may only be made by way of a testament (Art. 926, 941 et seq. of the CC) drawn up in a specific manner. Failure to preserve the required form invalidates the testament (Art. 958 of the CC). In the absence of a testament, legislation foresees an order of succession according to the hypothetical will of an abstract decedent, i.e., it sets forth

\footnotetext{
8 For instance, the requirement to meet certain criteria.

${ }^{9}$ In particular, the scope is broader in relationships governed by obligation law and narrower in the case of property law (Machnikowski, 2006, p. 420)

10 For instance, compare: Art. 74 of the CC.

${ }^{11}$ Compare: Art. 926, 941, 1047 of the CC.
} 
statutory succession (Pazdan, 2011, p. 982 et seq.). Thus, formless agreements on inheritance (that fail to meet formal requirements) have no binding legal force. Meanwhile, in practice the bequeather sometimes neglects to draw up the testament, trusting the assurances of their future heirs as to the possible division of the inheritance after death. It also happens that the bequeather, while preparing the testament, additionally reserves something outside of it or receives an oral assurance from the potential heir (devoid of an adequate form, not included in the testament, e.g. given as an instruction). ${ }^{12}$ The bequeather, acting out of trust, fails to predict the legal consequences of their actions. Yet after their death, in the light of a possible material gain, some people may seek a disposition in compliance with the testament, despite promises made to the descendant. Legislation does not foresee liability for the failure to perform agreements regarding inheritance. The lack of required form is penalized by the invalidity of such arrangements. Disloyal behaviour and assurances made to the deceased do not fall within the scope of Art. 928 of the CC, i.e. do not fit into the strict category of the heir's unworthiness. Assurances regarding succession should be treated only as a gentleman's agreement whose performance depends on the goodwill and honourable behaviour of the heirs. Established form of property disposition upon death is intended to ensure that the decedent had animus testandi and drew up the testament with due care. The form shall prove the contents of the testament in an attempt to avoid misunderstandings and conflicts. Thus, it appears that building relationships on trust in civil-law entities and their loyalty, without completing legal formalities, involves risk. Civil-law entities should consider that the laws on inheritance secure the rights of heirs (protect the interests of the parties).

\section{ACTIO PAULIANA}

If a debtor shows glaring disloyalty, i.e. not only fails to perform obligations but also parts with assets that could be subject to debt enforcement, the creditor is protected by the instrument of Actio pauliana, recognized in many legal systems (Art. 527 et seq. of the CC); (see also Carballo Piñeiro, 2012). The creditor may use Actio pauliana if the debtor acts in a nefarious manner, i.e. being aware of the detriment to the creditor(s) sells or otherwise disposes of their property or its part in order to reach insolvency and prevent debt recovery or render it difficult. ${ }^{13}$ As a result of the effective use of Actio pauliana (demonstration of the circumstances required), the creditor is entitled, with priority over other creditors, to satisfaction from the assets belonging to a third party. However, according to Art. 530 of the CC, if the third party has obtained a non-gratuitous propertyrelated benefit, the creditor may demand the juridical act to be found ineffective only when the third party knew of the debtor's intent. A juridical act of the debtor carried out to the creditors' detriment remains effective for persons who failed to oppose it by bringing legal action, particularly in relations between the debtor and a third party who obtained material gain, and for other creditors (see also Jasińska, 2006, p. 61 et seq.).

\footnotetext{
12 For instance, the bequeather has appointed his ex-wife as heir to his entire estate, receiving her assurance that after his death, she will provide for his current wife and their children. In the eyes of the law, the ex-wife is the sole heir. If she behaves disloyally and goes back on her assurance, the current wife is not entitled to protection.

${ }^{13}$ Compare: Judgment of the Supreme Court of 6 October 2017, case reference No. V CZ 68/17, Lex No. 2407352.
} 


\section{A DECLARATION OF INTENT MADE FOR THE SAKE OF FALSE APPEARANCES}

In the context of discussing loyalty, the institution of appearances deserves special attention. At present, acting only for appearances is quite common in many areas of social life, not only in economic relationships. ${ }^{14}$ Pursuant to Art. 83 of the CC, a declaration of intent made to another party for the sake of false appearances shall be invalid (absolute simulation). Where such a declaration was made to conceal another juridical act, the validity of the declaration shall be judged according to the nature of this juridical act (relative simulation). Simulation is a peculiar defect in that the declarant of intent makes an informed decision to express particular intent and decides that the declaration of intent will not have the legal consequences that it normally entails. A defect in the form of a simulation can, therefore, be declared in a situation where the declaration of will is made to the other party for false appearance's sake, i.e. without any intention to produce legal effects, and the other party is aware of the fictitious nature of the declaration and accepts the absence of intention to produce legal effects. ${ }^{15}$ Polish legislation does not question the legality of simulation since its legal consequences are indicated only in the event of disclosure.

Simulation involves two aspects of loyalty. On one hand, contract loyalty arising from the agreement between parties, on the other, disloyalty towards other participants in the economy. If the agreement regarding simulation is not disclosed, i.e. nobody learns of its fictitious nature, the juridical act in question will be regarded as fully effective in terms of economic exchange. Mutual 'contractual' loyalty between the parties leads to a situation where the legal environment has a misconception regarding the facts (appearances are made). Without a doubt, such behaviour is disloyal to other participants in the economy. From this perspective, simulation is undesirable in the economy, but often harmless.

The current judicial practice in Poland shows that simulation and the application of Art. 83 of the CC result not only in the invalidation of the declaration of intent made for the sake of false appearances but also, in case of relative simulation, in the invalidation of the concealed juridical act. ${ }^{16}$ Legal consequences foreseen in legislation do not recognize 'contractual' loyalty. To prove that, let us observe that 'contractual' loyalty of parties involved in the simulation usually falters in the face of a conflict of interest, e.g. if a party sees an opportunity for gain by renouncing the fictitious contract ${ }^{17}$. The civil-law party then transfers their loyalties by renouncing the agreement, and Art. 83 of the CC is applied. The ruling usually favours the party which renounced the agreement (the original arrangements). It could be inferred that Art. 83 of the CC is a punishment for the party which behaved loyally, i.e. honoured the agreement. This perspective points to a conclusion, or at least a need for discussion, that legislation should treat such cases in a special manner, i.e. strive to respect the original agreements between parties, while regulating the factual state so as to prevent any violation of the law and the rights of third parties (cf. Lewandowska, 2018b, p. 165 et seq).

\footnotetext{
14 Simulated acts and states include diseases, pregnancy, death, marriage, profitable trades, judgments, and even crimes.

15 Judgment of the Supreme Court of 13 August 2015, case reference No. I CSK 786/14 (lex database, No. 1866880).

16 Judgment of the Supreme Court of 12 October 2001, case reference No. V CKN 631/00, OSNC 7-8 (2002), p. 91

17 The simulation may be disclosed also if it is known to a third party or in another manner.
} 


\section{SIMULATED AUTHORSHIP}

A similar problem arises in case of the so-called simulated authorship (for this term, see Lewandowska, 2018a), often referred to as ghostwriting (see also Bassett, 2015; Lerman, 2001, p. 476). Simulated authorship involves creative work, i.e. the domain governed by copyright law, which de facto includes no provisions on the issue. Since the phenomenon encompasses a series of situations and forms, reference books distinguish several forms, i.e. ghost-writing, ghost painting, ghost composing (Czub, 2016, p. 126) and speechwriting (Wojnicka \& Giesen, 2013, p. 325), legal ghost-writing ${ }^{18}$. In the framework of simulated authorship, the author gives their informed consent for the authorship to be ascribed to another person and to the distribution of the work without disclosing the contribution of the actual author or as joint authorship (despite the lack of contribution of the other person). In principle, this leads to the transfer of a nontransferable moral right (the right to authorship is a moral right) in breach of the applicable law ${ }^{19}$. A case in point is the issue of dissertation purchases by students, which not only constitutes a violation of Art. 16.1 of the Act on Copyright and Related Rights ${ }^{20}$, but also is forbidden under Art. 76 of the Law on Higher Education and Science ${ }^{21}$. Similarly to the simulation governed by Art. 83 of the CC, if the entities involved in simulated authorship behave loyally (avoid a conflict) ${ }^{22}$, the reality established normatively (compare: Art. 8 of the Polish Act on Copyright), as perceived by the legal environment, shall remain as agreed by the parties. In this situation, loyalty to the informal agreement is illegitimate. The parties act in breach of the law, which implies that their will cannot be recognized on account of 'contractual' loyalty.

\section{CONCLUSION}

The conducted analysis shows that loyalty in civil-law regulations refers to decency, which is expected from civil-law entities. This fuzzy but fundamental term gains more clarity in particular regulations. In this manner, the legislation considers the differing scope or level of loyalty in various situations, for example at the stage of pre-contractual negotiations and for the duration of the contract.

In some cases, the disloyalty of civil-law entities is not penalized. Not for the lack of relevant regulations, but as a consequence of the choices made by the parties, e.g. regarding the form of their juridical acts. By discussing the issue of simulation and simulated authorship, it was demonstrated that some of the current legislative solutions fail to consider all aspects of loyalty, which calls for treating such situations in a special manner.

It could be argued that categories of norms, wherein broadly understood loyalty plays a special role, are a part of the civil-law principles (e.g. prohibition on the abuse of rights, party autonomy, or protection of trust). Loyalty, reconstructed with reference to a series of legal norms, points to the values that should be enshrined in legislation, sets a direction for future legislative activity and law application, defines the boundaries limiting civil-law entities in the use of their rights. Therefore, the introduction of the duty of loyalty,

\footnotetext{
18 If a given procedural document contains e.g. an original and creative interpretation of the law, it meets the conditions required of a work as defined in the Polish Copyright Law (see Piszczek, 2013, p. 819).

19 Some cases of simulated authorship are socially accepted, which does not change the fact that there is no legal resolution concerning their acceptability (cf. Jankowska, 2014).

20 Act of 4 February 1994 on Copyright and Related Rights (Dz.U. of 2018, item 1191).

${ }^{21}$ Act of 20 July 2018 on Higher Education and Science (Dz.U. 2018, item 1668).

22 Unless the simulation is disclosed by a third party or another special situation occurs.
} 
imposed in a general directive regarding conduct (lex generalis) would be undesirable. Such a regulation, devoid of any practical application, would raise nothing but a litany of doubts regarding its proper interpretation.

\section{BIBLIOGRAPHY:}

Bassett, D. L. (2015). Characterizing Ghostwriting. St. Mary's Journal on Legal Malpractice \& Ethics, 5(2), 284-310. Retrieved 13 March 2020 from https:// papers. ssrn.com/sol3/papers.cfm?abstract_id $=2616443$.

Carballo Piñeiro, L. (2012). Acción pauliana e integración europea : una propuesta de ley aplicable. Revista Española de Derecho Internacional, LXIV(1), 43-72.

Colombo, S. (1993). The Present Differences between the Civil Law and Common Law Worlds with Regard to Culpa in Contrahendo. Tilburg Foreign Law Review, 2(4), 341-375. Retrieved 13 March 2020 from https://papers.ssrn.com/sol3/ papers. cfm?abstract_id=1033430.

Czub, K. (2016). Prawo własności intelektualnej. Zarys wykładu. Warsaw: Wolters Kluwer.

Czub, K. (2018). Art. 72(1). In M. Habdas \& M. Fras (Eds.), Kodeks cywilny. Komentarz, Tom I. Część ogólna (art. 1-125) (pp. 685-694). Warsaw: Wolters Kluwer.

Erp, S. van. (2004). The Pre-contractual Stage. In A. Hartkamp, M. Hesselink, E. Hondius, C. Joustra, E. du Perron, \& M. Veldman (Eds.), Towards a European Civil Code (3rd ed., pp. 363-380). The Hague, London \& Boston: Kluwer Law International/ Nijmegen: Ars Aequi Libri.

Grzybczyk, K. (2012). Prawo reklamy. Warsaw: Wolters Kluwer.

Han, S. (2014). Culpa in Contrahendo in Chinese Contract Law. Tsinghua China Law Review, 6(2), 157-170. Retrieved 13 March 2020 from https://papers.ssrn. $\mathrm{com} / \mathrm{sol} 3 /$ papers.cfm?abstract_id=2677214.

Jankowska, M. (2014). Ghostwriting revisited. Zeszyty Naukowe Uniwersytetu Jagiellońskiego, (3), 99-128.

Jasińska, M. (2006). Skarga pauliańska. Ochrona wierzycieli w razie niewypłacalności dłużnika. Art. 527-534 KC. Komentarz. Warsaw: C.H.BECK.

Jugastru, C. (2012). Damage in the Presence of Justificatory Cases. Acta Universitatis Lucian Blaga, (1), 86-128.

Kaczorowska, B. (2011). Wizja wykładni umów w projekcie księgi pierwszej Kodeksu cywilnego. Transformacje Prawa Prywatnego, (1), 9-32.

Köhler, H. (2004). BGB Allgemeiner Teil. München: C.H.BECK.

Lekkas, S.-I., \& Tzanakopoulos, A. (2014). 'Pacta sunt servanda' versus flexibility in the suspension and termination of treaties. In C. J. Tams, A. Tzanakopoulos, \& A. Zimmerman (Eds.), Research Handbook on the Law of Treaties (pp. 312-340). Cheltenham: Edward Elgar. Retrieved 13 March 2020 from http://www.e-elgar. com/bookentry_main.lasso?id=14486\&breadcrumlink=\&breadcrum=\&sub_values=

Lerman, L. G. (2001). Misattribution in Legal Scholarship : Plagiarism, Ghostwriting, and Authorship. South Texas Law Review, 42(2), 467-492. Retrieved 13 March 2020 from https://scholarship.law.edu/cgi/viewcontent.cgi? article=1433 \&context =scholar.

Lewandowska, E. (2018a). Ghostwriting, ghostpainting, ghostcomposing... czyli o pozornym autorstwie. In M. Królikowskia-Olczak, D. Ossowska-Salamonowicz, M. Salamonowicz, \& A. Cekała (Eds.), Gospodarka rynkowa a rynek wewnętrzny Unii Europejskiej (pp. 39-48). Olsztyn: Wydział Prawa i Administracji UWM. 
Retrieved 13 March 2020 from http://wpia.uwm.edu.pl/czytelnia/index. php?option=com_ phocadownload\&view=category\&id=32:e-seriewpia\&lang=pl.

Lewandowska, E. (2018 b). Pozorność oświadczenia woli. Studium cywilnoprawne. Olsztyn: Wydział Prawa i Administracji UWM. Retrieved 13 March 2020 from http://wpia.uwm.edu.pl/czytelnia/index.php?option=com_phocadownload\&view= category\&id=32:e-seriewpia\&lang=pl.

Lewaszkiewicz-Petrykowska, B. (1973). Wady oświadczenia woli w polskim prawie cywilnym. Warsaw: Wydawn. Prawnicze.

Luo, Y., \& Ye, Q. (2019). Understanding Consumers' Loyalty to an Online Outshopping Platform: The Role of Social Capital and Perceived Value. Sustainability, 11(19), 5371. Retrieved 13 March 2020 from https://doi.org/10.3390/su11195371

Machnikowski, P. (2006). Umowy. § 22. Pojęcie umowy w prawie polskim, funkcje umów. Żródła prawa regulującego umowy. In E. Łętowska (Ed.), Prawo zobowiązań - część ogólna. System Prawa Prywatnego. Tom. 5. (pp. 420-434). Warszawa: C.H.BECK.

Mangu, F. I. (2015). The Relationship between Tort by Its Own Act and Vicarious Tort Liability. Acta Universitatis Lucian Blaga, (1), 56-67.

Opalska, D. (2013). Lojalność i staranność jako kryteria określające sposób wykonywania zobowiązań. Monitor Prawniczy, (5), 231-232.

Pazdan, M. (2011). Księga czwarta. Spadki. Wprowadzenie. In K. Pietrzykowski (Ed.), Kodeks cywilny. Tom II Komentarz do artykułów 450-1088. Przepisy wprowadzające (pp. 982-989). Warszawa: C.H. BECK.

Piszczek, J. A. (2013). _. In A. Matlak \& S. Stanisławska-Kloc (Eds.), Spory o własność intelektualną. Księga jubileuszowa dedykowana Profesorom Januszowi Barcie i Ryszardowi Markiewiczowi. (p. 1530). Warsaw: Lex a Wolters Kluwer business.

Pokrzywniak, J. (2003). Obowiązek lojalności jako element stosunku obligacyjnego. Monitor Prawniczy, (19), 885.

Rauterberg, G., \& Talley, E. (2017). Contracting out of the fiduciary duty of loyalty: An empirical analysis of corporate opportunity waivers. Columbia Law Review, 5, 1075-1152.

Sørensen, K. E. (2010). Duty of Loyalty of Shareholders - A Possible Remedy for Conflicts in SMEs? In M. Neville \& K. E. Sørensen (Eds.), Company Law and SMEs (pp. 127-170). København: Thomson Reuters. Retrieved 13 March 2020 from https://doi.org/10.2139/ssrn.1709944

Świerczyńska, D. (2001). Przysłowia są... na wszystko. Warszawa: Wydawnictwo naukowe PWN.

Trzebiatowski, M. (2011). Glosa do wyroku SN z dnia 22 czerwca 2010 r., IV CSK 359/09. Glosa, (1), 58-67.

Veljanovski, C. G. (2007). Contract. In Economic Principles of Law (pp. 109-180). Cambridge: Cambridge University Press. Retrieved 13 March 2020 from https://doi.org/10.1017/CB09780511611155.005

Winiarz, J. (2010). Prawa i obowiązki małżonków. In K. Pietrzykowski (Ed.), Kodeks rodzinny i opiekuńczy. Komentarz (pp. 284-324). Warszawa: C.H. BECK.

Wirtz, R. S. (2018). Good faith and the morals of the Marketplace. Quinnipiac Law Review, 36(2), 231-296.

Witte, J. J. (2001). The Goods and Goals of Marriage. Notre Dame Law Review, 76(3), 1019-1071.

Wojnicka, E., \& Giesen, B. (2013). Autorskie prawa osobiste. System Prawa Prywatnego, Prawo Autorskie, 13. 
Zagrobelny, K. (2008). Kodeks cywilny. Komentarz. (E. Gniewek,Ed.) (3rd ed.). Warsaw: C.H.BECK. 